\title{
5. Sociae
}

EISSN 2620-4975

ISSN 1410-3745

\section{QUO VADIS EU ENVIRONMENTAL DIPLOMACY?}

\author{
${ }^{1}$ Ellya Dameria Enesca, ${ }^{2}$ Ivonne Easteria Riyadi \\ ${ }^{12}$ International Relations, Universitas Kristen Indonesia, Jakarta \\ 1ellyadameria@gmail.com, ${ }^{2}$ msvonvon33@gmail.com
}

\begin{abstract}
Environmental issues should be a priority in the study of the current post-modern era of international relations. The after-effects of industrialization and technological progress have a very crucial impact on the global environment. Hence, we begin to examine the contemporary history of the efforts of the European countries as the first spearhead of the industrial revolution in dealing with the environmental crisis. The European Union is experiencing a lot of issues, commonly in the case of Environmental Diplomacy. Quo vadis is a Latin phrase meaning "Where are you going?". From this term, it will be seen how the problems that occur as well as the future that will be confronted with the aid of the EU. EU used to be in conflict with countless events such as with the United States, China, Indonesia, and even had its very own members, specifically Britain.
\end{abstract}

Keywords : Environmental Diplomacy, United States, Indonesia, European Union

DOI: 10.33541/sp.v21i1.1959

Sociae Polites : Majalah IImiah Sosial Politik

Faculty of Social and Political Science, Universitas Kristen Indonesia

ISSN 1410-3745 print/ ISSN 2620-4975 online

Volume 21, Number 1 (January - June 2020)

Pages 192-204 


\section{Introduction}

The Latin phrase "natura non contristatur" means that "the natural world is not sad or compassionate," it may be very appropriate when interpreted with the current conditions happening all over the world. Indeed, nature will not be sad if we treat it unkindly, but it will also not show mercy when it takes the burden and trashes we throw at them for too long. A significant but straightforward expression should make us aware of our need for nature, and our attachment to them. Maybe that's also one of the reasons why we decided to write this book.

The study of the environment is still rare, especially in social fields, because there are still many people out there who still hold the mindset that "it has become an obligation for mother nature to meet our needs," but it is not. Nature will continue even if humans do not exist. The negligence of humans seems to make some kind of paradox, that on the one hand, we know that nature was formed earlier than humans. Still, it has the power that can destroy us and can continue without us. Yet, on the other hand, we assume that because we are more intelligent, therefore we're more powerful and irresponsible to care for nature. Such a paradox, isn't it? So it leads us to the main question, then was there any attempt to change the situation? Do we ever care for nature as we care for the people that live in it? The answer is yes, Here's the brief introduction on how we picture the supranation organization such as European Union do their best to change the relationship between human and nature and how we manage to how we adjust to changes that are happening in the scale of technology, speed, and interconnectivity. And we're going to do it first by explaining it in chronological order. So here it comes the first step, the contemporary history of EU environmental diplomacy.

\section{Literature Review}

The Lisbon Treaty gives Europe new tools to combat climate change. Europe has to decide whether to leverage the European External Action Service to avert another breakdown of global environmental leadership, such as Copenhagen. The failure at the Copenhagen climate conference to obtain a real global climate deal contradicts the EU 's strategy of working multilaterally through the UN. In the post-Copenhagen climate talks, Europe will be reviewed. Within the multipolar system of global policy, Europe loses the negotiating power of China and the US.

Since the UN and international organizations like the G20 are not adopting the process, it is unclear whether specific parties are pursuing discussions outside of existing structures. To the leaders of Europe, there is no clear choice. Yet the European Union 's current eco-policy needs to be strengthened. A unique opportunity to improve research efficiency and develop the right instruments and mechanisms for the confrontment of climate change is the European External Action Service (EEAS), the European Union's new foreign services.

The repercussions of the fiasco go far beyond climate change for the European Economy. Environmental change is no longer merely a matter of the climate. Interconnected problems at the heart of dynamic power structures are economic development, energy stability, and environmental protection. In the multilateral climate cycle, actions have consequences for the sustainability of global governance systems. Such actions would also lead to establishing ties with the main external allies of the EU, 
including the US, Russia, China, and India. The European Union has to be interested in this geopolitical stage if it wants to become a credible global player.

Energy protection and climate change, and hence its systems of management, are identified as primary focus areas in the updated European Security Strategy 2008. In fact, in separate Council Conclusions, Member States agree that climate change and foreign health consequences are part of the broader EU agenda, including the European Foreign and Security Policy and energy protection. The study emphasizes climate change as a 'danger multiplier.' The recently named President of the European Council, his current international policies, and the EEAS are altogether becoming a significant platform for the European Union to gain a more considerable global reputation.

In a multilateral background since Copenhagen, the EU will rethink its diplomatic strategy. China is hesitant, and America can not be the main driver. Unless the EU wants to conclude that global climate policy is important, it must take dramatic action in its climate diplomacy. The negotiation in Oslo will still be a melting pot. Nevertheless, the European Union will also need to take into account other bilateral and regional arrangements and other willing 'coalitions,' such as the 'G-3' of the United States, China (or the newly formed BASIC Group of States) and the EU, for at least an interim period. After all, the United States and China contribute well over 40 percent of all greenhouse gases.

Two multilateral fora of free cooperation between world economies are conducted at the G7 and the G20 meetings. The congresses are especially important in the European Union to press for the adoption of the Sustainable Development Goals (SDGs). Ecologic Institute accepts the EU charge to strengthen the ECU position in the talks on this proposal. The department provides specialist advice in the areas of resource creation, circular economy, aquatic pollution, plastics, and environmental economy (Laky, 2019).

The previous passage highlights the fact that the world is experiencing environmental change and hence new challenges on a tech scale, speed, and interconnectedness that are unprecedented. The complete enforcement of the European Union's environmental laws is essential, although specific goals also have to be met. Yet, it is clear that objectives will unintentionally interrupt or reverse an aim in one field by unintentional effects. The goal is to establish synergies and co-benefits in the creation of one-of-a-kind domain names of effect assessments of regulations by utilizing approaches that take account entirely of natural resources.

Environment-based legislation has traditionally offered a wide variety of benefits by laws, regulations, and taxes, including social and economic benefits. The financial sector has been recognized by such laws to go far above what might usually be necessary. For starters, the input, output, and generation sectors of the economic system may not have expanded as quickly as they had without significant fitness tests without tightening air pollutant standards and improvements to wastewater treatment.

To several citizens in Europe, health, spiritual and environmental programs have improved, sustainable campaigns and extraordinary developments have raised their awareness and concerns. Some main benefits to date include increased financing strategies to create new industries to maintain jobs, gaming for businesses inside the domestic market; promoting technology changes to creativity and advantages for customers. 


\section{Results and Discussions}

\subsection{Quo-Vadis of EU Environmental Diplomacy}

The European Union is experiencing a lot of issues, mainly in the case of Environmental Diplomacy. The environmental diplomacy can be preceded by warfare inside the EU itself, fellow members, the Brexit case. The European Union has succeeded in organizing essential positions and potentially in world governance on climate. In this case, Britain is an extensive supporter of local weather action both in the EU and in local weather negotiations at some stage in the world.

Furthermore, in its climate diplomacy, the EU has succeeded in giving examples of climate action, such as forming a central role. The European Union has a vital position in climate trade by under the EU is a massive emitter of greenhouse gas emissions from world emissions. Second, the European Union leads three different matters to assist climate exchange to happen. Third, the European Union performs a position in national political lifestyles in Europe.

Within the European Union, Britain is a fundamental member. Britain has a massive typical diplomatic provider (14\% of diplomats are in the European Union). Then what happens after Britain leaves the EU is damage to EU climate action because the referendum will not be removed. The European Union tends to decline after Brexit; the EU will lose the economic contribution made by the UK to a budget that covers $14 \%$ of expenditure in 2015. There are plans for $25 \%$ of the post-2020 EU budget for climate initiatives and insurance policies, each internally and externally.

The Brexit trouble makes the terrible effect more significant. The negative consequences are, the EU Piracy Agenda, the taking of human and administrative resources, the liberation of the UK at existing is nevertheless a member and the Uncertainty. Besides, there are positive impacts through the EU, where some areas act more like barriers. Still, the UK can reach the route for Germany, which has succeeded in pushing for an extra advanced EU renewable power and binding countrywide goals for the EU. EU individuals have come to be advantageous energy effectivity producers for its citizens, together with British citizens. In the end, the EU became helpless but persisted.

In addition to the Brexit case, there is combat with China, concerning solar panels. China debates the issue of air pollution. The solution to this struggle can be found thru the Chinese leadership, which is an increasing number of focused on the ecological limits of fast monetary growth and working with the EU intensively on climate change and environmental policies.

In retrospect, before the 1990s, the European Union had collaborated with China on climate change problems and environmental policies. This function begins to alternate after the mechanism will become formal interaction. The European Union and China signify as defending economic hobbies that are not in line with political stress and the hazard of exchange war.

Then on June 25, 2012, a crew of European photovoltaic panel manufacturers, led using the highest solar panel producer in Europe, Solar World Germany, petitioned the European Commission against the alleged dumping of imported photovoltaic panel merchandise from China into the European market. Moreover, on September 6, 2012, the European Commission decided to start lookup on the most extensive exchange fighting problem between the EU and China. China's solar manufacturing enterprise has a skilled, 
fast increase in view that 2000. Looking returned in the 1990s, solar power producers count numbers carefully on the central government due to slow solar electricity manufacturing and the lack of authorities incentives for production and innovation in solar energy.

In this case, the dispute is the rate between Chinese and European producers. China added change reforms and carbon emissions to the country's environmental decision-making institutions, and both are actively supported via the EU. The combat between China and the European Union has a connection; however, China violates the rules they made themselves due to the fact of dumplings. In the future, this case needs to be beneath the supervision of the WTO and be given suitable sanctions.

After the warfare with China, the editors will talk about the Paris Agreement. The Paris Agreement is the first multilateral settlement at the beginning of the 21 st century that addresses a similar problem, which calls for stalled crossings in the system of making global law proposed through numerous scholars. The United Nations Framework Convention on Climate Change (UNFCCC) addresses the troubles of emissions, adaptation, and greenhouse fuel finance.

The European Union, the US, China and India, and the island nation, are preserving UN negotiations on a local weather agreement. The Paris Agreement makes comprehensive policies for the development, implementation, and approval of policies that have been made for global device approval. Secrecy does decrease the variety of actors, which is more comprehensive as a limit in negotiations. So the ultimate result is specific and not open to renegotiation. Politically, the Paris Agreement helps developed nations in the North because they win most of the battle of interests.

It is considering that the Paris Agreement has a weaker side, namely long-term global goals, compensation for loss and damage, technology transfer, and adaptation policies. The European Union formally reprimands this option because the agreement remains the cornerstone of global efforts that aim to tackle climate change effectively and cannot be renegotiated. A unanimous internal US withdrawal agreement causes the US exit. The Paris Agreement does not contain constitutional clauses that would strengthen a party to bring legal action before an international tribunal, and the state must first depend on the diplomatic mechanism established by an agreement.

Furthermore, the editors will talk about conflicts with the United States related to GMOs. GMOs (Genetically modified organisms) are offspring whose genes have been modified the usage of genetic engineering techniques. The procedure of making GMOs (biotechnology) can change the composition of the surroundings so that it can be toxic. The presence of GMO vegetation performs an essential position in countrywide meals security.

GMOs have a terrible impact on GMOs, which are acknowledged to have problems and risks alongside the growing use of GMOs. GMO products are very probable to affect human health, meals, health, and environmental problems that arise as a result of GMOs. The effects determined that the use of GMOs can injury the environment and the species that exist in that environment.

The United States considers that GMO products are the same agricultural products as conventionally grown agrarian merchandise so that they do not need to be explicitly handled. The purpose of the introduction of GMOs as one of the efforts for food security.

The European Union produced GMO products and kept excessive standards of fitness and environmental protection. The EU also has strict principles, and GMOs are the implementation of the precautionary principle. Two international locations in Europe 
have biotech vegetation covering solely 0.1 million hectares, in contrast, and 72.9 million in the US.

Without precedent for the historical past of GMO acceptance in the EU, in 2017, only two international locations planted maize, which used to be hereditarily changed, particularly Spain and Portugal. Then Germany delivered the purpose of coexistence between GMs, non-GMs, and natural planting in 2005, at the same time, Germany modified the definition of GMOs to protect towards environmental pollution via GM factories.

Starting from the Brexit conflict, the Solar Panel, the Paris Agreement, as well as the GMO, the European Union is also experiencing conflicts with Indonesia related to Palm Oil. The EU-Indonesia oil palm dispute is included in the EU environmental diplomacy issue. The palm oil industry is the critical engine of Indonesia's economic boom; however, it is claimed not to care about environmental justice and environmental protection. The EU Renewable Energy Direction (RED) is a manifestation of formidable environmental diplomacy that focuses on reversing monetary globalization and limiting economic growth. Fossil fuels are the predominant driver of local weather exchange because of its recognition as the biggest producer of carbon dioxide. However, renewable energy sources are nonetheless being debated. The use of wind and photovoltaic electricity is now not enough to reply to European power demand.

In 2015, renewable power only accounted for $13 \%$ of the total EU power consumption exceeding the quantity of oil and strong fuels by way of 50.6\%. On April 4, 2017, the European Union Parliament passed a resolution on palm oil and rainforest deforestation. The essential objective is to ban the import of oil palm, which is now not compatible with sustainable development and its spinoff products through 2020 into the EU.

Spain additionally contradicts the EU itself, which is positioned as a champion of open, rule-based, and honest trade. The issuance of this decision acquired severe interest from the Government of Indonesia. The decision made on palm oil does now not explicitly point out Indonesia. Still, the entire world knows that the most significant palm oil producer in the world is Indonesia, which is then observed by Malaysia, Thailand, Colombia, and quite a few other producing countries. What is worrying going forward is that different EU issues that are tighter on palm oil are also quicker to add to the meals or fitness industry. There are two necessary points associated to the practicable of the EUIndonesia war. First, the EU does not favor to be concerned in a trade war. Second, the EU and Indonesia have a consensus to unravel palm oil disputes in the World Trade Organization (WTO).

\subsection{The Future of EU Environmental Diplomacy (Revolution Industry)}

The European Union is classified as a supranational organization, the EU's capability that the European Union has an authority institution. The form resembles a country, has executive (European Commission) and legislative (Council of the European Union). The European Union includes the participation of the people, so that cooperation inside the institution is quite effective. One indicator to determine the degree of the strong integration of the European Union is the percentage stage of intra-EU exports of the total exports of the regional organization. The European Union has a 67.3\% rate in 2015 (CPF., 2008). 
But over time, the EU, which was constructed with the spirit of regionalism and the freedom to go, people, items, and capital, now faces resistance from its very own members. Its members, or as an alternative the majority of the people in their member countries, commence experiencing that the EU does not supply more benefits than the expenses it incurred.

Previously, it was once recognized that the EU used to be in war with several events such as with the United States, China, Indonesia, and even had its very own members, specifically Britain. As one of the most prosperous countries in Europe, Britain is a primary core for immigrants. So that at some stage in the Brexit case, the EU experienced a surprisingly sturdy shock.

In the past, EU local weather action performed aa vital position due to the fact OECD (Organization for Economic Co-operation and Development) and Non-OECD countries around the world took more ambitious moves than themselves. However, the EU is no longer a leader in local weather policy because other parties have pursued or even surpassed the EU. In some cases, the EU leadership resulted in different international locations, also copying EU policies, such as related to the European Union ETS and the German Renewable Energy Act (EEG).

According to the editor, the future of the European Union's Environmental Diplomacy is at an unsure point. After conflicts with different parties, the European Union cannot limit the danger that they will face a new conflict. For example, the world is being confronted through a COVID-19 pandemic. This pandemic made all countries try to rack their brains to deal with this case and discover a solution. Post-corona economic problems are a severe challenge to European countries. Factory closures, implementation of restrictions, and quarantine closures have hit the EU economy.

In truth, the European Union has taken anticipatory steps at the macro stage such as announcing the buy of 750 billion euros in bonds aimed at ensuring a calm market and defending the eurozone economy, delaying all corporate taxes and social tax alleviation, and promising authorities economic assistance to victims of Covid-19. Besides, the Group of 20, which includes numerous European nations and the European Union, has furnished 5,000 billion bucks to assist the world economy.

However, if the necessary conditions affecting Europe due to the unfold of Covid19 continue, and cohesion amongst EU member states is nevertheless low. The future of the EU surroundings will be threatened. The price range issued by way of the EU for the COVID-19 case can extend even more. Hence this will affect the finances for environmental issues. The European Union will also find it challenging to collaborate with other countries because every United States of America in the world experiences an identical problem. This pandemic can now not be decided in the future; it will stop like what, when, and how.

\subsection{Integrated Actions Across Policy Domains in Greening The Economy (Case Study)}

Environmental regulations have affected development practices and public wellbeing primarily. Consequently, they still discuss structural threats in part now. It is because the success made is overextended by other sources of environmental issues, including over-use of land and oceans. Such triggers also emerge from some factors and economic practices coupled with capital extraction for short-term gains. Reducing this requires multi-faceted collaboration that provides consistent and cost-effective outcomes 
that tackle investment fundamental to preserving resources within the ideals and longterm priorities of the community and lead towards the greening of the economy. Where environmental factors are associated with different outlets and economic practices, it is essential to maintain continuity as far as possible with the way we approach them. To optimize gains and prevent unexpected effects, divisions of the sector policies focused on the same tools often have the opportunity to enhance coherence in resolving specific environmental challenges. Examples of such quality are:

- Efficiency of Energy, Public Utilities, and Conservation of Habitats. The development of proven and evolving strategies in the field of environmental landscape management, as well as business strategy, in the key sectors (forests, agriculture, transportation, manufacturing, fisheries, maritime) ensuring the long term viability and productive use of renewable resources.

- Agriculture, forestry, marine, green infrastructure, and territorial cohesion. Developing green infrastructure and ecological networks on land and at sea to ensure the long-term sustainability and distributional gain of the terrestrial and marine communities of Europe.

- Sustainable production, intellectual property rights, trade, and aid. Implementing existing product standards and patents for innovation that accelerate substitution out of scarce and insecure non-renewable resources, reduce Europe's trade footprint, promote recycling potential, improve Europe's competitiveness and contribute to welfare improvements worldwide.

- Sustainable consumption, food, housing, and mobility. Integrating the three market areas which combine more than two-thirds of the world's significant environmental pressures from use in Europe.

In consideration of interlinks and the creation of cost-efficient approaches, increasingly cohesive strategies through many outlets of environmental risk now arise. The EU's environment and energy program are enabled, for example, by ties between climate change, decreased dependency on fossil fuels, green energy replacement, energy conservation, and multisectoral electricity demands. The EU policy represents a major change from 15-20 years ago and establishes a trend for more productive cooperation between sectoral and environmental concerns.

\section{Conclusions and Recommendations}

Although the future of the European Union is nonetheless unsure, and many awful things will likely happen, the EU also still has a hazard to enhance its very own future. The European Union can are searching for new relevance and find benefits for member states above the pursuits of neoliberal actors. The EU policy indeed suggests a small opportunity. However, a world except an EU is a world that is increasingly fragmented and inclined to open and pervasive conflicts.

The European Union is not alone. The EU has taken a local weather action, namely emissions trading. The EU Emissions Trading Scheme (EU ETS), the critical EU policy instrument for lowering GHG emissions and hence the cornerstone of its climate policy, used to be delivered in 2005. Today, it has been followed via an emission buying and selling gadget in Switzerland (2007), New Zea-land (2008 ), Northeastern United States (Regional Greenhouse Gas Initiative 2009), Tokyo (2010), Australia (2012), California, Kazakhstan, Québec, and Shenzhen in China (2013). 
The EU is additionally no longer some distance in advance of different countries concerning their home local weather efforts. If one looks at national mitigation movements from other countries, it turns into apparent that higher is being achieved in each OECD and different Non-OECD countries. The European Union has discovered its way into the considerations of the European Commission, which in March 2013 in the Green paper "Framework for 2030 for local weather and strength policy" claimed once more that the goal of a 30\% conditional emission reduction for 2020 had no longer been mobilized promises.

The European Union's bid to amplify its emissions reduction target with the aid of $20 \%$ to $30 \%$ under the 1990 baseline depends on the ambitious movements of different major emitters supposed to inspire them to set higher objectives themselves. However, preceding EU local weather policies not only influenced local weather action for the duration of the world.

Thus, the European Union has the chance to enhance family members with other countries after the hostilities and change its future for the better. There are nevertheless many things and initiatives that can be executed with the aid of the European Union, thinking that the European Union is the most significant and most active regional corporation when compared to comparable organizations such as ASEAN and NAFTA. Some consider the EU to be a super-state due to the fact it has a parliament and a central bank. The warfare passed by using the European Union is a stepping stone to turning into an improved regional organization than before. 


\section{BIBLIOGRAPHY}

Bals, C., Cuntz, C., Caspar, O., \& Burck, J. (2013). The End of EU Climate Leadership. Germanwatch Briefing Paper, 1-20.

Bocse, A. M. (2020). The UK's decision to leave the European Union (Brexit) and its impact on the EU as a climate change actor. Climate Policy, 20(2), 265-274. https://doi.org/10.1080/14693062.2019.1701402

CPF., L. (2008). Masyarakat Asia Tenggara Menuju Komunts ASEAN 2015 . Yogyakarta: P2P LIPI \& Pustaka Pelajar.

Laky, Z. (2019, November 1). Environment policy: general principles and basic framework. Retrieved from European Parliament: https://www.europarl.europa.eu/factsheets/en/sheet/71/vides-politika-visparigiprincipi-unpamatsistema\#: :text=European\%20environment\%20policy\%20dates\%20back, called $\% 20$ for $\% 20$ an\%20action\%20programme

Martin, A., \& Pramono, S. (2011). FAKTOR-FAKTOR PENDORONG INTEGRASI REGIONAL : Studi Perbandingan Uni Eropa dan ASEAN. Spektrum, 8(1), 25-43.

Pavone, I. R. (2018). The Paris Agreement and the Trump administration: Road to nowhere? Journal of International Studies, 11(1), 34-49.

https://doi.org/10.14254/2071-8330.2018/11-1/3 